\title{
The distibution of Elatine hydropiper L. (Elatinaceae)
}

\author{
Agnieszka Anna Popiela ${ }^{1 *}$, Andrzej Rafał Łysko ${ }^{2}$, Anetta Wieczorek ${ }^{3}$, Attila Molnár V. ${ }^{4}$ \\ ${ }^{1}$ Department of Botany and Nature Conservation, University of Szczecin, Felczaka 3c, 71-412 Szczecin, Poland \\ ${ }^{2}$ Department of Environmental Protection and Management, Western Pomeranian University of Technology, Słowackiego 17, 71-43 Szczecin, Poland \\ ${ }^{3}$ Department of Ecology, University of Szczecin, Wąska 13, 71-415 Szczecin, Poland \\ ${ }^{4}$ Department of Botany, University of Debrecen, Egyetem sq. 1, 4032 Debrecen, Hungary
}

\section{Abstract}

A distribution map of Elatine hydropiper L. (Elatinaceae), which belongs to the Euro-Siberian phytogeographic element, has been prepared based on literature and web-based data. The distribution range of the taxon, comparison to previous maps and reliability of the results are discussed.

Keywords: vascular plants, Elatinella, map, chorology, Isoëto-Nanojuncetea, Europe, Asia

\section{Introduction}

Elatine hydropiper L. is a tiny, inconspicuous plant of aquatic and seasonally flooded habitats. It belongs to a small, cosmopolitan family Elatinaceae that has been comprised in taxonomic system in various manners over the last century, which reflects its uncertain phylogenetic position (see for example [1-5]). Molecular studies have supported the old hypothesis of Cambessedes [6], comprising the family within the order Malphigiales, while the closest taxonomic relations seeing between Elatinaeae and Malpigiaceae, a tropical family of mostly trees and shrubs $[7,8]$.

The family Elatinaceae includes only two genera, i.e. Elatine and Bergia, the latter being mainly Old World tropical $[9,10]$. About 15-25 species of the genus Elatine are being found in both hemispheres in moderate climate. In subgenus Elatine (species with opposite leaves) E. hydropiper is one of the eight species comprised in the section Elatinella, a double number of stamens in relation to petals being its distinctive feature [9]. Seven species of this section is being found in Europe, i.e. E. brochonii Clavaud, E. gussonei (Sommier) Brullo \& al., E. hexandra (Lapierre) DC. E. hungarica Moesz, E. hydropiper, E. macropoda Guss. and E. orthosperma Düben, some of them also in North Africa, three in Europe and North Asia (E. hungarica, E. hydropiper and E. orthosperma), and one in North America (E. californica Gray) [9,11-17]. Although the distribution areas of most taxa of the section Elatinella are rather well

\footnotetext{
*Corresponding author. Email: popiela@univ.szczecin.pl

This is an Open Access digital version of the article distributed under the terms of the Creative Commons Attribution 3.0 License (creativecommons.org/licenses/by/3.0/), which permits redistribution, commercial and non-commercial, provided that the article is properly cited.
}

known, quite much work is still needed to check identity of all already now available data and herbarium material. There are also new data being gathered while mapping methods with the use of satellite base maps allow preparation of more precise maps in various scales at present.

The aim of this paper is to present the distribution of Elatine hydropiper in the world on the basis of current data and to discuss of the state of knowledge of this range.

\section{Material and methods}

The area of Elatine hydropiper is presented based on floristic and phyotosociologial literature (analogue data in the form of location list, information about positions or maps) and webbased sources (electronic data; Tab. 1). Locations were placed if taxon description raised no taxonomic doubts, in some cases, it was possible to verify the identity from specimens at the Kew Herbarium (K), the Herbarium of Natural History Museum in London (BM) and the Herbarium of Botanischer Garten und Botanisches Museum Berlin-Dahlem (B). In case of accurate literature source data, they had priority over the web-based ones. Web-based data were placed on the map only when they seemed to be reliable, i.e. they did not deviate from the range, had an author and exact location or were delivered by herbarium servers. Altogether, there were 2816 floristic data analysed, including 1523 literature and herbarium data and 1293 ones coming from web-based sources; 1068 web-based data were removed because they were to be found in literature or seemed to be unreliable. To sum up, the maps were made on the basis of 1748 floristic data, including 225 ones coming from web-based sources. The maps (Fig. 1, Fig. 2) illustrate localities of E. hydropiper s. str., i.e., they do not include localities of E. orthosperma Düben and Elatine spathulata Gorski, except those determined by Uotila to E. hydropiper s. str. (see $[12,18])$. Furthermore, the localities given under names generally accepted synonyms of $E$. hydropiper s. str., were used, i.e. 
Tab. 1 Literature and web sources from which data where used to present the distribution of Elatine hydropiper.

Area Dat

\section{$[11,12,18,37,38]$}

Data provided by: EUNIS - European Environment Agency, Vascular plant collection of Jyvaskyla University Museum - Jyväskylä University Museum - The Section of Natural Sciences, Paleobiology Database - Marine Science Institute, UCSB, Herbarium of Oskarshamn (OHN) - GBIF-Sweden, Lund Botanical Museum (LD) - GBIF-Sweden, Plants (GBIFSE:Artdatabanken) - GBIF-Sweden, Botany (UPS) - GBIF-Sweden, Vascular Plant Herbarium, Oslo (O) - Natural History Museum, University of Oslo, Vascular Plants, Field notes, Oslo (O) - Natural History Museum, University of Oslo, University Museums of Norway (MUSIT), Hatikka Observation Data Gateway - Finnish Museum of Natural History, National Vegetation Data bank - NLBIF, Wetland Inventory (NV) - GBIF-Sweden, Vascular plant herbarium, Agder naturmuseum og botaniske hage - Natural History Museum, University of Oslo, Vascular Plants, Field notes, Agder naturmuseum (KMN) - Natural History Museum, University of Oslo, Vascular Plant Herbarium, Trondheim (TRH) - Natural History Museum, University of Oslo, Vascular Plants, Field notes, Trondheim (TRH) - Natural History Museum, University of Oslo (Accessed through GBIF Data Portal [39])

The middle, southern and eastern Europe and northern Asia [17,20-29,40-91]

The western and southwestern Europe and northern Africa [36,92-108]

(the British Islands, France, Belgium, the Netherlands,

Germany, Switzerland, Algeria)

Elatine hydropiper subsp. gyrosperma, Elatine schkuhriana K. Heyne, Elatine oederi Moesz, Elatine hydropiper subsp. oederi (Moesz) F. Herm., Elatine hexandra subsp. major (A. Braun) Arcang., Elatine gyrosperma (Fr.) Meinsh., and E. hydropiper var. major (A. Braun) Fiori.

Analogue data were mapped manually using satellite base map. In case of paper maps, calibration and rectification to UTM grid was made earlier and digitalisation was performed. The vector layers prepared this way were converted to WGS84 cartographic grid. Electronic data containing geographical coordinates were exported to ${ }^{*}$.shp format and then, due to their diversity, were given common cartographic system WGS84. When geographical coordinates were missing, they were converted into text format and then, in case of detailed information about position, a record was digitalised manually on a satellite base map prepared earlier. When accurate description was missing and position was given in cartogram grid only, a cartogram was made according to principles for a given atlas followed by using spatial queries connecting grid area with map. All analyses and maps were made using PostGIS spatial database extension software as well as QGIS application software operating in the LINUX environment.

\section{Results}

Elatine hydropiper belongs to the Holarctic element, the Euro-Siberian sub-element (distinction consistent with the approach of Pawłowska [19]). The presented maps (Fig. 1, Fig. 2) point to the concentration of locations in the Central and Northern Europe although a clear reduction in the density of locations towards the east may be caused by poorer botanical survey of these areas, further data in local publications are not so easy to trade and could be omitted. The European range seems to be well-known: most locations is being found in
Central European lowland, mainly in river valleys, with the eastern limit of its dense range being reached in the western part of Poland and the western one in the Rhine Valley and the central part of the Bohemian Massif. Single locations or location clusters are being found in France (Seine Valley, South Loire River Basin) as well as in western England, Wales, south-western Scotland and north-eastern Ireland. It is very rarely reported from South and Southeastern Europe (to the south of the Alps and the Carpathian Mountains). It is frequently reported in south-eastern Norway, southern Sweden and south-eastern Finland as well as in the area of the Gulf of Finland. There are single locations known in Belarus, Ukraine, the Baltic Countries and in the European part of Russia. In Siberia, the species occurs mainly in the valleys of Ob, Irtysh, Yenisei and Angara Rivers as well as on Lake Baikal.

\section{Discussion}

Despite the very variable form and shape of oblong leaves, Elatine hydropiper is a taxon having rather well-defined morphological features. Quadruple, sessile flowers, eight stamens and horseshoe-shaped seeds are the most important ones of them. It can be confused with E. californica, E. gussonei and E. hungarica with which it is most closely related and which also have very characteristic horse-shaped or strongly curved seeds but flowers have pedicels (also short ones). The correct determination requires a stereomicroscope, and the additional problem is that under unfavorable conditions plants may remain sterile, and, also, several species grows often mixed. The first tow taxa are also characterised by completely different geographical range, i.e. E. californica is a North-American species (western part of the continent) while E. gussonei is probably an endemic species of the Mediterranean islands, Malta and Lampedusa. The distribution of E. hungarica is poorly known 


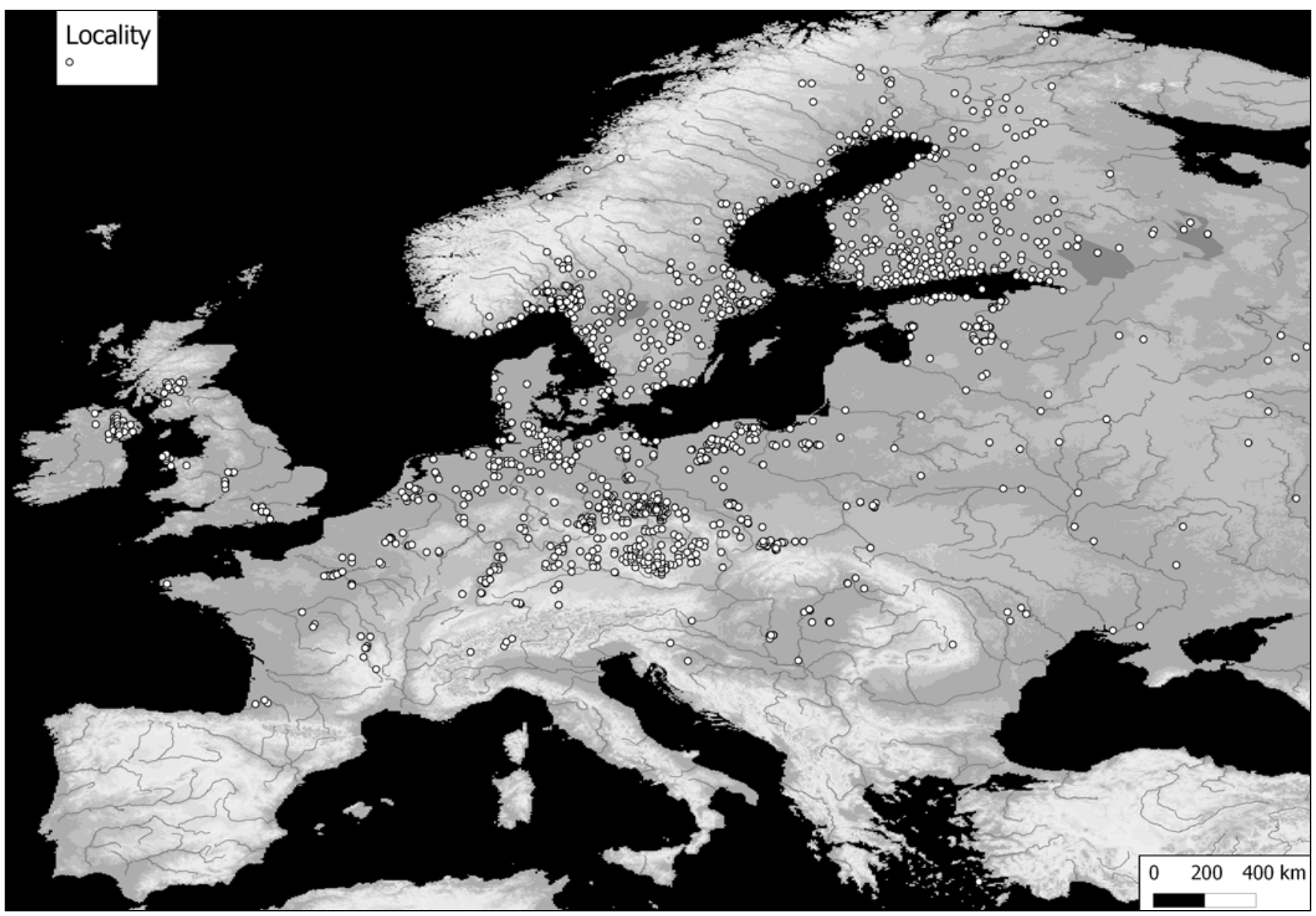

Fig. 1 Distribution of Elatine hydropiper L. in Europe.

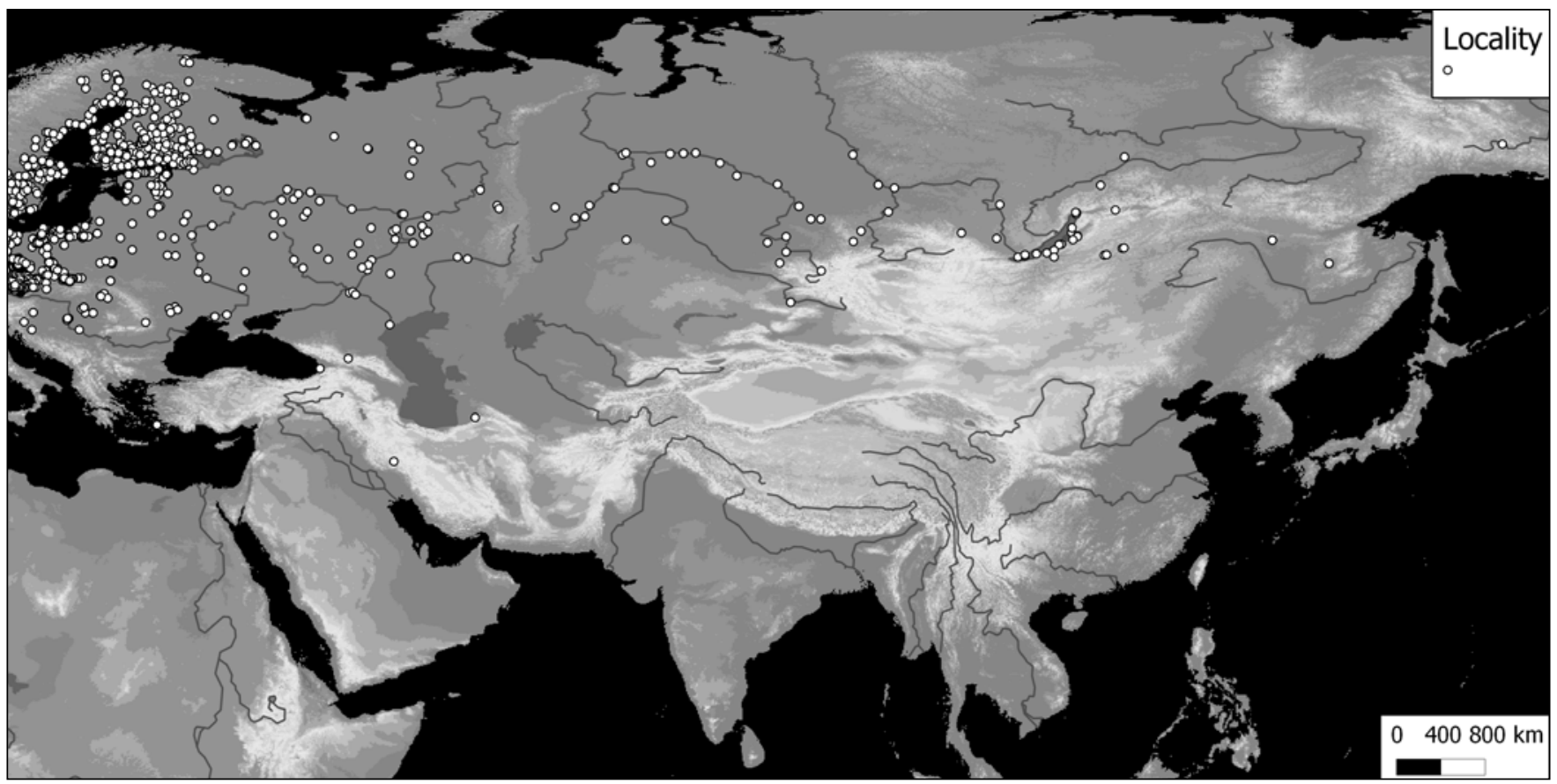

Fig. 2 Distribution of Elatine hydropiper L. in East Europe and Asia. 
but most probably Euro-Asiatic, being however more southern and eastern compared with E. hydropiper [9,15,20-24]. The range of E. hydropiper overlaps to large extent (at least in the northern part) that of E. orthosperma, being however well distinguishable from it if fruit-bearing specimens are collected (straight seeds in E. orthosperma); see also Uotila [12,18].

Like all other species of this genus, Elatine hydropiper is being found in shallow waters and in places undergoing seasonal floods. In North Europe (Scandinavia), these are most often shallow waters of lakes and calm (stagnant) waters of rivers (most frequently to $50 \mathrm{~cm}$ deep), rarely on wet soil above the water line, also in ditches and ponds. In Central Europe, it is most frequently reported on the shores and bottoms of seasonally dried fish breeding ponds while certain historic locations are from natural habitats - lake shores, river banks and old river-beds. The latter habitats are also most frequently reported from East Europe and North Asia [12,18,20,25-31]. E. hydropiper is most frequently being found in communities of the alliance Elatini-Eleocharition ovatae, in patches of the association Eleocharo-Caricetum bohemicae Klika 1935 (syn. Heleocharetum ovatae Moor 1936) [30,32,33] and aquatic communities of the alliance Isoëtion [34].

The genus Elatine in the northern hemisphere has most probably a long history going back at least to the early Tertiary and floras of this period: the Mediterranean Tertiary and the Madrean Tertiary ones ([16,17] and references cited there), whereas the present range of the species was formed in Holocene. The formation of distribution range of ephemeral wetland flora through general dispersal of diaspores by water and marsh birds (exozoochoria) is possible; but this phenomenon is however very poorly examined, while no documentation is available for the genus Elatine at all ([35] and references cited there, as well [36]). The distribution of $E$. hydropiper requires further examination. It is relatively well known in Central Europe; it has a form of smaller and larger site clusters which are frequently far away from each other, even many kilometers away. They are mainly located in the valleys of major rivers. If this reflects the true distribution of the species, disjunctions inside the range occurring, indicate that the spreading of diaspores does not occur easily while the range pattern has a relatively stable character. Most locations known at present in Central Europe are being reported from habitats of the anthropogenic origin, namely from drained fish ponds seasonally flooded. This indicates to anthropogenic expansion of the home range of the taxon under discussion, at least with regard to the number of locations. In European parts of Russia and in Asia most analysed floras confirm the occurrence of E. hydropiper whereas their locations are being rarely reported. Therefore, in such areas their study is necessary, and in the meantime the species distribution can be determined only hypothetically.

One of the basic problems in mapping the distribution of Elatine hydropiper were differences in the quality of data and the methods being used for their preparation. Geographic co-ordinates were easiest to find for literature and herbarium floristic data. Published maps are a much less accurate source; we used cartogram- and point-type maps. Data transfer from cartogram-type maps is always burdened with error which results from the size of basic cartogram unit. Differentiated scale of point-type maps is often an obstacle for their matching to geographic space. Paper maps are made at a specific scale and when it is being increased the points lose detail. Additionally, when using information on maps, it is required to bring them to uniform co-ordinate system. In this study, the universal WGS 84 co-ordinate system was used, while the maps being used by us are made in local or regional co-ordinate systems. The best method is calibration of maps in the system, in which they were made, followed by their vectorisation and bringing to uniform co-ordinate system. Vector data are not prone to deformations as the raster ones and their greatest advantage is that each point can be given attributes in database comprising, among others, information about the location, author and data source. Moreover, such data do not lose quality when the map is being scaled up, while a point on it always preserves the specific scale. When compared to maps of E. hydropiper distribution being published earlier $[11,13,14]$, the maps presented here are characterised by larger amount of data (also those being freshly obtained or made available in the last twenty years) and much greater precision, which was allowed by the mapping method adopted.

\section{Acknowledgements}

Funding was provided to by the Ministry of Science and Higher Education (project No. PO4C03525). We wish to thank keepers of the Kew Herbarium, the Herbarium of Nature History Museum in London, and Botanischer Garten und Botanisches Museum Berlin-Dahlem for providing access to herbarium materials. We thank an anonymous reviewer for valuable comments and suggestions.

\section{References}

1. Hutchinson J. The families of flowering plants, arranged according to a new system based on their probable phylogeny, dicotyledons. London: Macmillan; 1926. (vol 1).

2. Niedenzu F. Elatinaceae. In: Engler A, Prantl K, editors. Die natürlichen Pflanzenfamilien. Leipzig: W. Engelmann; 1925. p. 270-276. (vol 21).

3. Wettstein R, von Wettstein F. Handbuch der systematischen Botanik. 4th ed. Leipzig: F. Deuticke; 1935.

4. Cronquist A. The evolution and classification of flowering plants. 2nd ed. Bronx NY: New York Botanical Garden; 1988.

5. Takhtajan AL. Diversity and classification of flowering plants. New York: Columbia University Press; 1997.

6. Cambessèdes J. Note sur les Elatinées, nouvelle famille de plantes. Paris: impr. A. Belin; 1829.

7. Heywood VH, Brummitt RK, Culham A, Seberg O. Flowering plant families of the world. Kew: Royal Botanic Gardens; 2007.

8. Davis CC, Chase MW. Elatinaceae are sister to Malpighiaceae; Peridiscaceae belong to Saxifragales. Am J Bot. 2004;91(2):262-273. http://dx.doi.org/10.3732/ajb.91.2.262

9. Tucker GC. The genera of Elatinaceae in the southeastern United States. J Arnold Arbor. 1986;67:471-483.

10. Leach GJ. Taxonomic revision of Bergia (Elatinaceae) in Australia. J Adelaide Bot Gard. 1989;11(2):75-100.

11. Hultén E. The circumpolar plants. 2. Dicotyledones. Handlingar. 1971;13(1):1-463.

12. Uotila P. Elatine hydropiper L. aggr. in Northern Europe. Memo Soc Fauna Flora Fenn. 1974;50:113-123.

13. Hultén E, Fries M. Atlas of North European vascular plants, north of the Tropic of Cancer. Königstein: Koeltz; 1986. 
14. von Lampe M. Wuchsform, Wuchsrhythmus und Verbreitung der Arten der Zwergbinsengesellschaften. Dissertationes Botanicae. 1996;266:1-351.

15. Mifsud S. A comparative study between Elatine gussonei (from Malta) and Elatine macropoda (from Majorka) [Internet]. 2006 [cited 2009 Aug 7]; Available from: http:// www.aquatic-gardeners.org/elatine.html

16. Popiela A, Łysko A. The distribution of Elatine macropoda Guss. (Elatinaceae). Acta Soc Bot Pol. 2010;79(1):81-86.

17. Popiela A, Prajs B, Łysko A. New data on the distribution of dwarf ephemeral wetland vascular plant species and communities in western and north-western Poland. Biodiv Res Conserv. 2010;14:35-40.

18. Uotila P. Elatine. In: Flora Nordica. Stockholm: The Swedish Museum of Natural History; 2010. p. 62-69. (vol 6).

19. Pawłowska S. Charakterystyka statystyczna i elementy flory polskiej. In: Szafer W, Zarzycki K, editors. Szata roślinna Polski. Warsaw: Polish Scientific Publishers PWN; 1972. p. 129-206. (vol 1).

20. Majevsky PF. Flora of middle belt of the European part of the USSR. Moscow: Selkhozgiz; 1954.

21. Pavlov NV, editor. Flora of Kazakhstan. Alma-Ata: Academy of Science Kazakh SSR; 1963. (vol 6).

22. Shishkin BK, Bobrov EG. Flora of the USSR. Jerusalem: Israel Program for Scientific Translations; 1974. (vol 15).

23. Tzvelev NN, editor. Elatinaceae. In: Flora Wostocznoj Evropy. Saint Petersburg: Mir i Sem; 1996. p. 178-180. (vol 9).

24. Molnar VA, Pfeiffer N. Adatok a hazai Nanocyperion-fajok ismeretéhez II. Iszapnövényzet-kutatás az ár- és belvizek évében Magyarországon. Kitaibelia. 1999;4(2):391-421.

25. Malyshev LI, Peshkova GA. Rare plants of Central Siberia. Novosibirsk: Nauka; 1979.

26. Adylov TA, editor. Conspectus florae Asiae Mediae. Tashkent: Institutum Botanicum Academiae Scientiarium USSR; 1983. (vol 7).

27. Prokudin JN, editor. Opredelitel' vysšich rastenij Ukrainy. Kiev: Naukova Dumka; 1987.

28. Sinelnikova NV, Taran GS. Nachodka associacii CyperoLimoselletum (Oberd. 1957) Korneck 1960 (IsoëtoNanojuncetea) v Magadanskoj oblasti. Rastitel'nost' Rossii. 2003;4:90-92.

29. Arhipova EA, Berezutsky MA, Bochkova AY, Kostetsky OV, Sedova OV, Serova LA, et al. New and rare species in the flora of Saratov Region. Botaniczeskij Zhurnal. 2007;92(8):1235-1240.

30. Popiela A. Isoëto-Nanojuncetea species and plant communities in their eastern distribution range (Poland). Phytocoenologia. 2005;35(2-3):283-304. http://dx.doi. org/10.1127/0340-269X/2005/0035-0283

31. Šumberová K, Lososová Z, Fabšičová M, Horáková V. Variability of vegetation of exposed pond bottoms in relation to management and environmental factors. Preslia. 2006;78:235-252.

32. Brullo S, Minissale P. Considerazioni sintassonomiche sulla classe Isoëto-Nanojuncetea. Itinera Geobotanica. 1998;11:263-290.

33. Popiela A, Łysko A, Wieczorek A, Nalepka D. The distribution of Elatine hexandra Lapierre (Elatinaceae). Acta Soc Bot Pol. 2011;80(1):27-32.

34. Murphy KJ. Plant communities and plant diversity in softwater lakes of northern Europe. Aquat Bot. 2002;73(4):287324. http://dx.doi.org/10.1016/S0304-3770(02)00028-1

35. Deil U. A review on habitats, plant traits and vegetation of ephemeral wetlands - a global perspective. Phytocoenologia. 2005;35(2):533-706. http://dx.doi. org/10.1127/0340-269X/2005/0035-0533

36. Brinkkemper O, Weeda EJ, Bohncke SJP, Kuijper WJ. The past and present occurrence of Elatine and implications for palaeoenvironmental reconstructions. Veg Hist Archaeobot. 2007;17(1):15-24. http://dx.doi.org/10.1007/ s00334-007-0104-Z

37. Faegri K, Danielson A. Maps of distribution of Norwegian vascular plants. Bergen: University of Bergen Botanical Institute; 1996. (vol 3).

38. Edqvist M, Karlsson T, editors. Smålands flora. Uppsala: Föreningen Smålands Flora; 2007.

39. GBIF Data Portal [Internet]. 2011 [cited 2011 Jul 17]; Available from: http://data.gbif.org

40. Cesati V, Passerini G, Gibelli G. Compendio della flora Italiana. Milano: Vallardi; 1867.

41. Szmallhausen I. Flora srednej i yuzhnyı̆ Rosiji, Kryma i na severnom Kavkaze. Kijev: Ekatierinskaja; 1895. (vol 1).

42. Fiori A, Paloetti G. Flora analitica d'Italia. Padova: Tipografia del Seminario; 1896. (vol 1).

43. Korshinsky S. Tentamen florae Rossiae orientalis. Mémoires de l'Académie Impériale des Sciences de St. Pétersbourg. Classe physic-mathématique. 1898;7:82-83.

44. Krylov P. Flora of Western Siberia. Tomsk: Nauka; 1939. (vol 7).

45. Dobroczajeva DM. Elatinaceae. In: Klokov MV, Visulina OD, editors. Flora URCR. Kiev: Akademija Nauk Ukrainskoi RSR; 1955. p. 313-318. (vol 7).

46. Topa E. Elatinaceae. In: Săvulescu T, editor. Flora Republicii Popularne Romine. Bucharest: Editura Academiei Republicii Populare Romine; 1955. p. 541-545.

47. Sokolovskaya AP. Elatinaceae. In: Shishkin BK, editor. Flora Leningradskoj obłasti. Leningrad: Izdatel'stvo Leningradskogo Universiteta; 1961. p. 181-183. (vol 3).

48. Grossheim AA. Flora Kavkaza. Moscow: USSR Academy of Sciences; 1962. (vol 6).

49. Popov MG, Busik VV. Abstract of flora of coasts of Lake Baikal. Moscow: Nauka; 1966.

50. Eilart J, Kask M, Kuusk V, Laasimer L, Lellep E, Puusepp V, et al. Eesti NSV Floora. Tallin: Valgus; 1973. (vol 5).

51. Trinajstič I, editor. Analitička flora Jugoslavije. Zagreb: Institut za Botaniku Sveucilišta u Zagreb; 1975. (vol 2).

52. Żukowski W. Rodzaj Elatine L. w Polsce. Bad Fizj Pol Zach ser Botanika. 1975;28:7-23.

53. Tolmatchev AI. Flora regionis boreali-orientalis terrtoriae Europaeae URSS. Leningrad: Nauka; 1976. (vol 3).

54. Malyshev LI, Sobolevskaja KA. Redkie i isčeżajuščie rastenika Sibiri. Novosibirsk: Nauka; 1980.

55. Soó R. A magyar flóra és vegetáció rendszertani-növényföldrajzi kézikönyve. Budapest: Akadémiai Kiadó; 1980. (vol 6).

56. Ramenskaya ML, Andreeva VN. Manual of the higher plants of Murmansk region and Karelia. Leningrad: Nauka; 1982.

57. Pignatti S. Flora D’Italia. Bologna: Edagricole; 1982. (vol 3).

58. Chochrjakov AP. Flora Magadanskoj Oblasti. Moscow: Nauka; 1985.

59. Tabaka L, Gawrilova G, Fatare I. Flora sosudistych rastenij Latvijskoj SSR. Riga: Zinatne; 1988.

60. Geideman TS. Key to the higher plants of Moldavian Soviet Socialist Republic. Kishinev: Shtiintsa; 1986.

61. Tichomirova WI. Opredelitiel rastenij Meščery. Moscow: 
Izdatelstvo Moskovskogo Universiteta; 1986. (vol 1).

62. Charkevicz SS, editor. Planatae vasculares orientis extremi Sovietici. Saint Petersburg: Nauka; 1987. (vol 2).

63. Dostál J. Nová květena ČSSR. Prague: Academia; 1989. (vol 1 pt 2).

64. Hejny S, Slavík B, editors. Květena České Republiky. Prague: Academia; 1990. (vol 2).

65. Slavík B. Fytokartografické syntézy ČSR. Phytogeographical syntheses of the ČSR. Průhonice: Botanical Institute of Czechoslovak Academy of Science; 1990. (vol 2).

66. Dostál J, Červenka M. Velký klúč na určovanie vyšších rastlín. Bratislava: Slovenske Pedagogicke Nakladatel'stvo; 1991. (vol 1).

67. Taran GS. Pojmennij efemeretum srednej obi - nowyj dlia Sibiri klass Isoeto-Nanojucetea Br.-Bl. et Tx. 1943 na severnom predele rasprostranenia. Siberian Journal of Ecology. 1994;1(6):595-599.

68. Cherepanov SK. Vascular plants of Russia and adjacent states (the former USSR). Cambridge: Cambridge University Press; 1995.

69. Sitnikov AP. Elatine hydropiper L. In: The red data book of the Republic of Tatarstan (animals, plants, fungi). Kazan: Priroda; 1995.

70. Taran GS. A little known vegetation class of the former USSR - flood-plain Ephemeretum (Isoëto-Nanojuncetea Br.-Bl. et Tx. 43). Siberian Journal of Ecology. 1995;2(4):372-380.

71. Trepin D, Vreš B. Register flore Slovenije. Ljubljana: Znanstvenoraziskovalni center SAZU; 1995.

72. Maemets A, Eglite Z, Sinkeviciene Z. Elatinaceae Dumort. In: Kuusk V, Tabaka L, Yankyavichene R, editors. Flora of the Baltic countries: compendium of vascular plants. Tartu: Eesti Loodusfoto AS; 1996. p. 198-199. (vol 2).

73. Petković B, Martin P, Tatić B. Genus Elatine L. in the flora of Serbia. 2 Kongres na biolozite na Makedonja (so medjunarodno učestvo); Ohrid, Macedonia. Ohrid: Zbornik na apstrakti; 1998. p. 24.

74. Popiela A. Nowe stanowiska gatunków z rodzaju Elatine L. w Polsce. Bad Fizj Pol Zach ser Botanika. 1998;47:257-264.

75. Popiela A. Elatine hydropiper L. In: Zając A, Zając M, editors. Distribution atlas of vascular plants in Poland. Kraków: Laboratory of Computer Chorology, Institute of Botany, Jagiellonian University; 2001.

76. Kritzkaia LI, editor. Opredelitel' vysšich rastienij Ukrainy. Kiev: PJF; 1999.

77. Mosyakin SL, Fedoronchuk MM. Vascular plants of Ukraine: a nomenclatural checklist. Kiev: National Academy of Sciences of Ukraine, M.G. Kholodny Institute of Botany; 1999.

78. Prokudin JN, editor. Opredelitel' vysšich rastenij Ukrainy. Kiev: Naukova Dumka; 1999.

79. Zheng-Yi W, Raven PH, editors. Flora of China. Cycadaceae through Fagaceae. Saint Luis: Missouri Botanical Garden Press; 1999. (vol 4).

80. Bojkov TG, editor. Krasnaja kniga respubliki Burjatija: redkie i iscezajušcie vidy rastenij i gribov. Novosibirsk: Nauka Siborskoe; 2002.

81. Bojkov TG, editor. Unikal'nye ob"ekty rastitel'nogo mira Central'noj Sibiri. Novosibirsk: Nauka; 2005.

82. Maemets H, Maemets A. Commented list of macrophyte taxa of lake Peipsi. Proc Estonian Acad Sci Biol Ecol. 2000;49(1):136-154.

83. Kwiatkowski P. Notatki florystyczne z Gór Kaczawskich i ich Pogórza (Sudety Zachodnie). Cz. 2. Fragm Flor Geobot Polonica. 2002;9:55-65.

84. Spałek K. Nadwodnik naprzeciwlistny - Elatine hydropiper L. Em Oeder. In: Nowak A, Spałek K, editors. Czerwona księga roślin województwa opolskiego. Rośliny naczyniowe wymarłe, zagrożone i rzadkie. Opole: Opolskie Towarzystwo Przyjaciół Nauk; 2002. p. 72.

85. Dubovik DV. Elatine hydropiper L. In: Khoruzhik LI, Suschenya IM, Parfenov VI, editors. Red data book of Bielarus plants. Minsk: Bielarus Encyclopedia Publication; 2005. p. 81-82.

86. Kukk T, Kull T, editors. Atlas of the Estonian flora. Tartu: Institute of Agricultural and Environmental Sciences of the Estonian University of Life Sciences; 2005.

87. Peschkova GA. Flora of Siberia: Geraniaceae-Cornaceae. Enfield: Science Publishers; 2006. (vol 10).

88. Sinelnikova NV, Taran GS. Bank vegetation (Isoeto-Nanojuncetea, Phragmito-Magnocaricetea) of the Kolyma River upper reaches, Russian far east. Saint Petersburg: Vegetation of Russia; 2006. (vol 9).

89. Jouharchi MR, Akhani H. Notes on the flora of Iran 6: Eight new plant records from Iran collected from Khorasan and Golestan Provinces (NE Iran). Rostaniha. 2006;7(2 suppl):131-141.

90. Stebel A, Nejfeld P, Stebel AM. Nawodnik naprzeciwlistny. In: Mirek Z, Piękoś-Mirkowa H, editors. Czerwona księga Karpat Polskich. Rośliny naczyniowe. Kraków: W. Szafer Institute of Botany, Polish Academy of Sciences; 2008. p. 134-135.

91. Valeyeva EI, Glazunov GA. Natural complex of "Surgut" wildlife refuge [Internet]. 2009 [cited 2009 Jun 10]; Available from: http://www.ipdn.ru

92. Boreau A. Flore du centre de la France et du bassin de la Loire. Paris: Librairie encyclopédique de Roret; 1849.

93. Legrand A. Constatation de deux espèces d'Elatine nouvelles pour le plateau central dela France. Bull Soc Bot Fr. 1879;26(1):149-150.

94. Lloyd J. Flore de louest de la France. Paris: Mme T. Veloppé; 1886.

95. Coste H. Flore descriptive et illustree de la France de la Corse et des contrées limitrophes. Paris: Libraire scientifique et Technique; 1937. (vol 1).

96. Quézel P, Santa S. Nouvelle flore de l’Algérie et des régions désertiques méridionales. Paris: Éditions du Centre national de la Recherche scientifique; 1962. (vol 2).

97. van Rompaey E, Delvosalle L. Atlas de la flore belge et luxembourgeoise. 2nd ed. Meise: Jardin Botanique National; 1979.

98. Corillion R. Flore et végétation de la vallée de la Loire (cours occidental: de l'Orléanais l'estuaire). Paris: Jouve; 1981.

99. Guinochet M, de Vilmorin R. Flore de France. Fasc. Paris: Centre National de la Recherche Scientifique; 1982. (vol 4).

100. Curtis TGF, McGough HN. The Irish red data book. Vascular plants. Dublin: Stationery Office; 1988. (vol 1).

101. Haeupler H, Schönfelder P, editors. Bildatlas der Farn- und Blütenpflanzen der BRD. Stuttgart: Verlag Eugen Ulmer; 1989.

102. Grenier E. Flore d'Auvergne. Lyon: Société linnéenne de Lyon; 1992.

103. Wohlgemuth T. Der Verbreitungsatlas der Farn- und Blütenpflanzen der Schweiz (Welten und Sutter 1982) auf EDV. Die Artenzahlen und ihre Abhängigkeit von 
verschiedenen Faktoren. Bot Helv. 1993;103:55-71.

104. Benkert D, Fukarek F, Korsch H, editors. Verbreitungsatlas der Farn- und Blütenpflanzen Ostdeutschlands. Jena: Gustav Fischer Verlag; 1996.

105. Preston CD, Pearman DA, Dines TD. New atlas of the British and Irish flora. Oxford: Oxford University Press; 2002.

106. Antonetti P, Brugel E, Kessler F, Barbe JP, Tort M. Atlas de la flore d'Auvergne. Chavaniac-Lafayette:
Conservatoire Botanique du Massif Central; 2006.

107. Gamisans J, Jeanmonod D. Catalogue des plantes vasculaires de la Corse. In: Jeanmonod D, Burdet HM, editors. Complements au Prodrome de la Flore de la Corse. Annexe nr 3. Geneva: Conservatoire et Jardin botaniques Ville de Genève; 1993.

108. La biodiversité en Wallonie [Internet]. 2011 [cited 2011 Jul 24]; Available from: http://biodiversite.wallonie.be 